\title{
The life world of the adolescent with mental health problems
}

\author{
T Peens, D.Cur, RAU \\ M Poggenpoel, Ph.D., RAU
}

\section{Abstract}

Adolescents are currently being more and more exposed to the expectations of parents, educators, health-workers/helpers and policy makers to meet the demands of society and conform to it. The perception arises that adults are not able to let the adolescent take responsibility for the HOW of his own life story, despite all the expectations and demands.

Under the influence of the post-modernistic approach to science and the narrative therapy it appears that each person is an expert of his own life and that each person is responsible for the how and the writing and rewriting of his own life story. This means that even the adolescent with mental health problems is busy with the writing and rewriting of his life story till even unpleasant incidents and experiences gain new meaning. This demands from the adolescent with mental health problems to be actively involved with his treatment program while the therapist is a participating observer of the therapeutic events. A one-sided approach, where the therapist's objectives and ideas make the difference in the treatment of adolescents with mental health problems, becomes redundant. An alternative approach is suggested where the adolescent with mental health problems becomes co-author of his own life story and his treatment program.

In this research the researcher aimed to explore and describe the HOW of the life world of the adolescent with mental health problems. The utilization of the case-study format as research method enabled an in-depth, holistic description of the life world of the adolescent with mental health problems. The implementation of the strategies to ensure trustworthiness, as described by Guba was applied to ensure the validity and reliability of this study.

Focus was specifically placed on the application of the strategy of cross validation. This implies that multiple datacollection sources, different experts, theories and respondents were utilized in the exploration of the life world of the adolescent with mental health problems before this life word was described in depth.

The researcher makes a few conclusions and based on these make recommendations for application in practice, education and research.

\section{Opsomming}

Adolessente word vandag al hoe meer blootgestel aan die verwagtinge van ouers, opvoeders, gesondheidswerkers/ helpers en beleidmakers om eventueel aan die eise van die samelewing te voldoen en daarmee te konformeer. Die persepsie untstaan dat volwassenes, ten spyte van hierdie verwagtinge en eise, nie die adolessent kan los om self verantwoordelikheid te begin aanvaar vir die HOE van sy eie lewenstorie nie.

Onder die invloed van 'n post-modernistiese wetenskapbeskouing en narratiewe terapie blyk dit egter dat elke mens self die ekspert van sy lewe is en dat elkeen self verantwoordelik is vir die hoe en die skryf en die herskryf van sy lewenstorie. Dit impliseer dat selfs die adolessent met geestesgesondheidsprobleme besig is met die skryf en die herskryf van sy lewenstorie totdat selfs onaangename gebeure en belewenisse nuwe betekenis kry. Dit verg egter van die adolessent met geestesgesondheidsprobleme om aktief betrokke te wees by sy behandelingsprogram terwyl die terapeut deelnemend waarnemer is van die terapeutiese gebeure. ' $n$ Eensydige benadering waar die terapeut die doelwitte en ideale vir die adolessent met geestesgesondheidsprobleme die verskil aan die behandeling maak, is uitgedien. "n Alternatiewe benadering waar die adolessent met geestesgesondheidsprobleme mede-outeur word van sy lewenstorie en sy behandelingsprogram word gesuggureer.

In hierdie navorsing beoog die navorser om die HOE van die leefwêreld van die adolessent met geestesgesondheidsprobleme te verken en te beskryf. Die gebruikmaking van die gevallestudie-formaat as navorsingsmetode het ' $n$ indiepte, holistiese beskrywing van die leefwêreld van die adolessent met geestesgesondheidsprobleme moontlik gemaak. Die implementering van die strategieë vir vertrouenswaardigheid soos deur Guba onderskryf, is deurlopend toegepas om die geldigheid en betroubaarheid van die studie te verseker. Daar is veral klem gelê op die toepassing van die strategie van kruisvalidasie. Dit impliseer dat daar in die verkenning van die leefwêreld van die adolessent met geestesgesondheidsprobleme deurlopend van meervoudige data-insamelingsbronne, verskillende deskundiges, teorieë en respondente gebruik gemaak is alvorens die leefwêreld in die resultaat in diepte beskryf is.

Ten slotte kom die navorser tot enkele gevolgtrekkings en doen op grond hiervan enkele aanbevelings vir toepassing in die praktyk, onderwys en navorsing. 


\section{Introduction}

More than a third of the South African population are between ten and nineteen years of age (Census 1991). The demands and expectations on this component of society, namely the adolescent, daily increases. Adults prescribe conformation to social demands, namely responsibility and maturity, to adolescents, from the adult's reference framework.

The adolescent is often denied the opportunity of choice and decision-making regarding the formation and development of a world vision, an own reference framework for an own identity, a norm and value-system, education, religion, health care, environment awareness, art and music, and even those things happening around and within the family (Walsh \& Middleton, 1984:31-33). Adults (parents, teachers, health authorities, advisors and policy makers), often ignore the demands and expectations the adolescent wants to comply with out of own free will and own choice. This approach also applies to the adolescent with mental health problems. Adults within a multiprofessional team decide where, when, how and what is necessary for the adolescent with mental health problems.

The preconceived ideas of parents, educators and team members have predetermined which expectations this adolescent must comply to before he/she can be declared "mentally healthy", without allowing the adolescent to become involved in his own treatment, or to provide any input into the matter. The perception is created that the adult, whether it is the parent or the professional team member or the whole team, takes responsibility for the adolescent.

Just like adults can not take responsibility for each other's decisions, the adolescent can not take responsibility for decisions taken by adults. Subsequently, adults can not take responsibility for decisions made by the adolescent. This perception results in separation from the concept. The way the reference framework of the adolescent with mental health problems is perceived by the adolescent on the one hand, and the parent/supervisor on the other hand, differ to such an extend, that an even greater separation between the two parties occur.

To understand the adolescent with mental health problems his life world must be better introduced to adults. Adults (parents, professional team members and therefor also the psychiatric nurse) should get involved as fellow-observers/participants in the life world of adolescents with mental health problems and should establish a relationship with the adolescent.

The post-modernistic scientific view indicates that every individual, because of his structure determination (Kotze, 1992:8) constructs his own reality in language and narratives and is therefore the expert of his own life story. This implies that not the researcher nor the professional helpers or the parents are experts on the life stories of adolescents with mental health problems, but that adolescents should take responsibility for the how of the writing of their own life stories. The adolescent should therefore be the main participant in deliberation of and have a final say in the design and application of his own life story (new and co-written) by constructing his reality. This implies that the adolescent with mental health problems is involved with and participate in deliberation regarding his treatment program in order to realize hope and the quest for whole- ness, restoration, maintenance and promotion of mental health.

\section{Problem Statement}

The researcher's involvement with the development of an adolescent unit and the implementation of programs on the basis of literature findings and discussions with expert therapists of adolescents, has irrespective of the challenge, created tiredness, despondency, frustration and powerlessness in the researcher and the staff working in the adolescent unit. The ideals of the adolescent with mental health problems were not taken into consideration. The researcher, under the impression of the post-modernistic approach, constructivism and narrative therapy, realized the importance of the individual's own expertise, and as such that of the adolescent with mental health problems. She realized that, unless the one-sided approach changes to an alternative approach where the adolescent with mental health problems is made aware of his involvement in designing his own life world, his own reality, and the fact that he is co-author of his own life story, and his own treatment program, he won't gain from treatment.

The following questions arose:

- How does the adolescent with mental health problems construct his own life world in all the dimensions applicable?

- How can the psychiatric nurse apply gained knowledge to the therapeutic program of the adolescent with mental health problems?

\section{Objective}

The objective of the study is to explore and describe the life world of the adolescent with mental health problems in-depth, utilizing multiple, explorative case studies and writing a crossincident report. The central statement: the understanding of the life world of the adolescent with mental health problems, in all its dimensions, by the psychiatric nurse, leads to the facilitation of the promotion, restoration and maintenance of mental health. Applying case-study methodology provides the researcher with the opportunity to understand the inherent knowledge of the phenomenon domain under discussion, namely the life world of the adolescent with mental health problems: the adolescent's condition, thoughts, feelings, behaviour, intentions and environment are investigated. As such, the gap between nursing research and -practice can be bridged (Polit \& Hungler, 1989:156).

\section{The Course of The Research: The Research Design And - method}

An explorative, descriptive, contextual and qualitative research design was utilized to better understand, and in-depth describe the realities and meanings of the life world of the adolescent with mental health problems, by means of language (narratives, dialogue and participating assessment).

Language is the medium used to structurally couple people to create a world that can be lived in; language is used by people to coordinate interactions (Kotze, 1992:56-58). Concrete concepts are generated by interaction, involvement and normal human activities such as observation, listening, talking and 
reading with the adolescent with mental health problems, in his own language, according to his own rules and boundaries and his own realities in life (Lincoln \& Guba, 1985: 199).

- The research design is explorative since the objective of the research is directed at gaining new sigh and a better understanding of the phenomenon domain;

- It is descriptive since the researcher wants to gather and describe accurate and exact information;

- It is contextual since the investigation and description of the life world of the adolescent with mental health problems is based on the information obtained from the narrative, dialogue and assessment of specific adolescents with mental health problems in a specific adolescent unit in a private psychiatric clinic in Gauteng, Republic of South Africa.

- It is qualitative since the researcher strives to study, understand and fully comprehend the group of adolescents in terms of their life world and perceptions of their contexts (Mouton \& Marais, 1988:44-45, 50, 70, 157, 162 \& 165; Lincoln \& Guba, 1985,"289-331; Krefting, 1991:214; Marshall \& Rossman, 1989:10,21).

A deep, holistic description of the life world of the adolescent group with mental health problems is illustrated utilizing exploratory and descriptive case studies and eventually a cross case study, according to a case record (Merriam, 1991:8-13; Yin, 1983:14-20,56 (Compare Diagram 1). At the same time the conclusions are controlled utilizing literature findings to ensure increased reliability (Woods \& Catanzaro, 1988:136). An understanding and knowledge of the life world of the adolescent with mental health problems becomes known to the researcher who uses multiple data-collection sources such as interviews (phenomenological- and focus single interviews), documentation (clinical records, field notes and spontaneous sketches), assessment and a literature survey.

During the unstructured phenomenological interviews the researcher asks each adolescent with mental health problems one covering question individually: "Tell me how you experience having a mental health problem." And in the focus single interview: How do you think your mental health problem can be solved?" in order to discover dynamic emotional processes, which to a large extend determine behaviour and to describe a deeper, more comprehensive understanding of the life world of the adolescent with mental health problems (Kvale, 1983; Omery, 1983:50-59; Kingry, Tiedje \& Friedman, 1990: 124; Kerlinger, 1986:444-446).

The clinical record of each adolescent is used to obtain all the

Diagram 1 : Case study framework

\title{
EXPLORATION AND DESCRIPTION OF H ELIFE WORLD OF HE ADOLESCENT WITH MENTAL HEALTH PROBLEMS
}

\author{
TRUSTWORTHINESS : \\ GUBA'S APPROACH \\ TEST SAMPLE : \\ PURPOSEFUL TEST SAMPLING
}

DATA-COLLECTION :

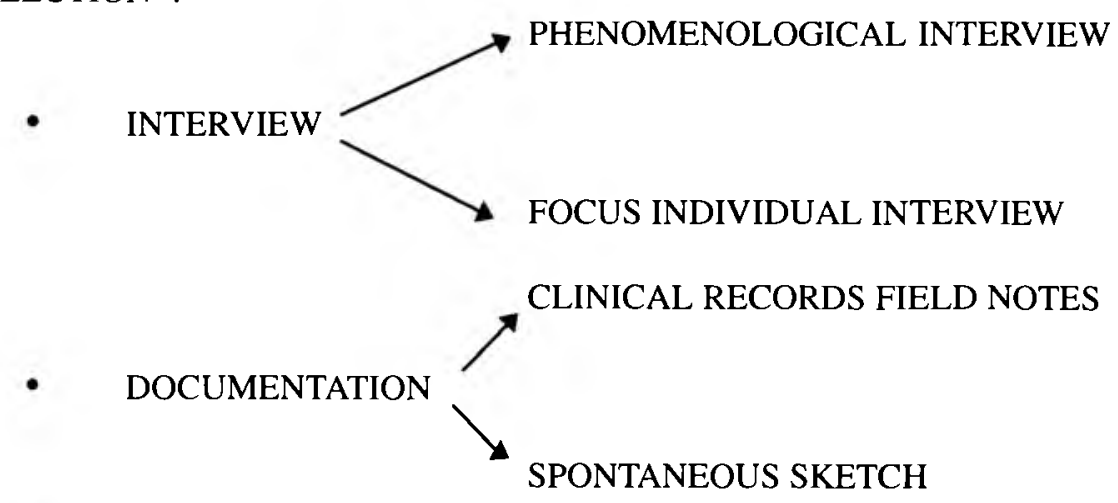

- $\quad$ ASSESSMENT AND FIELD NOTES

\author{
DATA PROCESSING : GIORGI AND KERLINGERS' COMBINED METHODS \\ COMPILATION OF A CASE STUDY \\ DESCRIPTION OF A CASE STUDY \\ LITERATURE CONTROL \\ DISCUSSION OF RESULTS AND CONCLUSION
}


biographic information (including name, surname, age, gender, facial structure, genogram, behavioural and emotional manifestations and scholastic data) and information regarding the treatment process. Each adolescent was requested to "write the story of his life". This spontaneous sketch was done at the beginning of the study. This provided new insight into the life world of the adolescent with mental health problems and according to Giorgio (1985:10-14) is the beginning of all phenomenological studies.

Assessment, as data-collection source, reflects the process the researcher utilizes to compare reality with theoretical assumptions as well as all incidents, behaviour and artifacts within the specific context written with openness and consciousness of own experiences with the assistance of tilorough and systematic field notes (Mouton \& Marais, 1988:164; Marshall \& Rossman, 1989:105-107).

A combination of inductive and deductive data processing was done over a period by three analysts individually and eventually together during consensus discussions using Giorgi's (1985: 10-14) and Kerlinger's (1986:447-483) guidelines for data analysis. All data obtained according to a purposeful and comfortable election (spontaneous sketch, the interviews transcribed verbatim, the field notes and photocopies of the clinical records) pertaining to the four adolescents with mental health problems was grouped into four individual parcels and together with the work protocol, handed over to two external Master's degree qualified psychiatric nursing specialist as coders, the researcher and the supervisor, as audit trail (Abdellah \& Levin, 1979:704; Omery 1983:57; Krefting, 1991:219-221).

Similar to data-collection a literature survey is done to highlight the repetition, differences and new data similar to the themes, patterns and values that were encountered in the description of the life world of the adolescent with mental health problems.

After consensus discussions a case-study report was written on each individual respondent according to the case study record described under the headings of biographic information; the adolescent's experience of his mental health problem. the adolescent's solution to his mental health problem and a summary.

In order to describe the life world of the adolescent with mental health problems holistically, in-depth and intensively, a crossreference report, according to the case study record, was written (see diagram 2).

\section{Trustworthiness Of The Study}

The validity of reliability of the study are ensured using Guba's (1981) model for trustworthiness in qualitative research and are discussed under the headings credibility, transferability, reliability and confirmability.

Implementing a couple of strategies the researcher briefly refers to, ensured credibility. The researcher spent considerable time (time test sampling-strategy) with the respondents whilst being introduced to them by a go-between; discussing the letters of consent and having it signed by both the adolescents and their parents; the spontaneous sketches were writ- ten in her presence; the various interviews were conducted; and she kept field notes of her perceptions without over-involvement and familiarity taking place.

At the same time the strategy of reflexivity is used that implies that the researcher remains in continuous contact with her own emotions, perceptions and background, discusses with her supervisor and colleagues, and don't allow it to influence the research process. She continuously reminds herself to the fact that she fulfills a double role; that the psychiatric nursing therapist and researcher, irrespective of the fact that she is part of the research domain.

The strategy of cross validation (triangulation) is applied collecting data in various ways, together with various experts (two advanced psychiatric nursing specialists and adolescents with mental health problems) over a period of approximately six months, with the assistance of various respondents and field workers collecting data in various ways, processing the data using more than one theory. It is this aspect the researcher wants to highlight in this article by applying the strategy and process of cross validation to the study.

The strategy of member checking increases credibility since the holistic, intensive description of the life world of the adolescent with mental health problems is confirmed by other adolescents with mental health problems from those who served as respondents.

The trustworthiness of the study is increased by the willingness of the researcher to discuss the research method, findings and process with her colleagues, coders and supervisor (peer group evaluation); conduct the interviews as accurately as possible, and record is on tape and correctly transcribe it verbatim and make field notes for coding and analysis purposes; her unique authority and status because of her familiarity with and distinct interest in the phenomenon on the basis of her conceptual and theoretical knowledge, her ability to investigate various theoretical perspectives and multi-professional approaches and hr ability to investigate the data, makes her appropriate to conduct the research (Krefting, 1991:217219; Van Reenen, 1993:44; Yin, 1989:14-20).

Qualitative research leaves no room for generalization, but for transferability of the uniqueness of each situation and the in depth, dense holistic description thereof, in order for "the responsibility of the original investigator (to) ends in providing sufficient descriptive data to make such similarity judgement possible. "(Lincoln \& Guba, 1985:298; Krefting, 1991:216).

The researcher confirms transferability firstly by making use of a case study format with the characteristics specifications (focus specific), description (a rich dense, holistic description and interpretation of the meaning of norms, values, attitudes and perceptions of the phenomenon), heuristic (contributes to the readers understanding and insight) and induction (discovery of new relationships, concepts and terminology). She acts as if someone is watching her the whole time and stores all collected data safely in order to have it available should anybody want to judge it (Yin, 1989:45). She secondly uses a panel of judges for the respondents to be representative of this life world of the adolescent with mental health problems (Krefting, 1991:220; Van Reenen, 1993:45). 


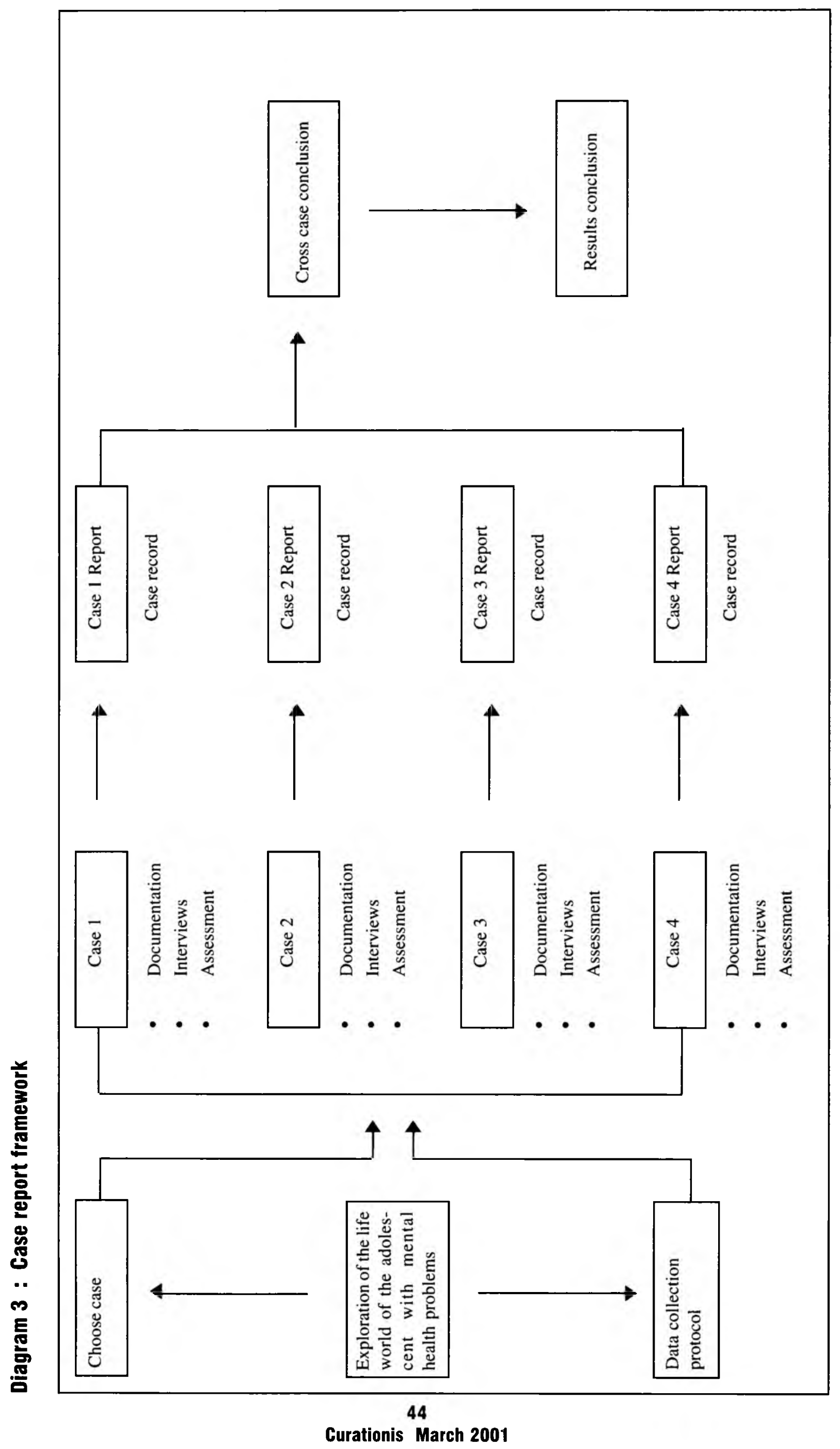


Reliability increases as every human situation in its diversity is explored and insight into a wide field of experiences of various respondents, where each specific experience is valuable, is collected. The researcher ensures the transferability and the uniqueness of the situation by applying exactly the same method of data collection, analysis and interpretation throughout the course of the research process. She uses a panel of judges for individual coding, where the strategy of code-recode is applied as well as joint consensus discussions.

Cross validation and peer group evaluation already mentioned, increase reliability (Krefting, 1991:216,221). It is eventually the confirmability audit, contained in the exact description of the research methodology and the course of the research, as well as insight into the manner decisions were made public to others, that confirms the trustworthiness of the study.

All raw data, up to the final product, is kept safely. This include spontaneous sketches, transcriptions of various interviews, photocopies of the clinical records, field notes, analysis of the researcher and coders, audio tapes, analysis and processing of consensus discussions, the case study records and the case documentation, the results and conclusions, as well as the sources of the literature survey. Cross validation and reflexivity increase confirmability.

\section{Application of the strategy cross validation}

The researcher specifically focused on utilizing cross validation to increase and confirm the trustworthiness of the study. Four kinds of cross validation was identified and all four kinds were thoroughly applied during the course of the study.

\section{Data collection methods}

The researcher used multiple data collection sources to provide an in-depth, holistic description of the life world of the adolescent with mental health problems. These sources for data collection include two different kinds of interviews (phenomenological and focus-single interviews), each respondent's clinical record, the spontaneous sketch and the researcher's assessment during the writing of these spontaneous sketches, the interviews and her general assessment during operation in the nit reflected in the field notes, as well as a literature control.

\section{Data sources}

Research extended over a period of twenty months where the researcher was intrinsically involved with the various groups of adolescents with mental health problems, collected and analyzed data and subsequently applied and processed the data. The processed data was discussed with various experts who were members of the multi-professional team, fellow psychiatric nursing specialists, the supervisor and adolescents with mental health problems.

The themes that were discovered in the stories of the life worlds of adolescents with mental health problems, have repeatedly been confirmed by the experts mentioned above. The processed data resulted in: the more extensive the development, the better the understanding of the adolescent with mental health problems.
A comprehensive circumspect sampling of various theories and literature was done before the literature survey from a nursing-, psychiatric nursing-, psychiatric-, psychological-, sociological and educational perspective was undertaken. The researcher, in the fourth place, made use of various respondents/ field workers. Four adolescents with mental health problems were used in the exploration and description of the life world of adolescents with mental health problems, whilst two advanced psychiatric nursing professionals were involved in analyzing and coding the data.

\section{Results: The description of the life world of adolescents with mental health problems}

The results originate from the information obtained from the multiple data collection sources, the processed data that was discussed with various experts, the literature findings and control of various theories and the use of various respondents and field workers. This therefore is the result of applying the cross validation strategy.

As a result of the meta-theoretical assumptions, the Nursing for the Whole Person Theory of the Oral Roberts University, Anna Vaughn School of Nursing, was utilized as theoretical framework to categorize the results of the explorative multiple case studies, reflected in the life world of the adolescent with mental health problems, under the headings: the physical dimension, the psychological dimension, the social dimension and the psychological dimension.

The physical dimension refers to "all biochemical processes (in the individual) as well as its structural and functional aspects." (Poggenpoel, Nolte, Dörfling, Greeff, Gross, Muller, Nel \& Roos 1994:132, as adapted). No themes were re-identified in this dimension and are reflected in the characteristic interactional manner.

The psychological dimension refers to "the carrier of all experience and behaviour" (Poggenpoel, et al, 1994:5) and includes the intellectual, emotional and deliberation processes. The identified intellectual themes include ineffective coping mechanisms as indicated in anorexia, alcohol abuse conflict, isolation and self-destructive behaviour.

In the emotional category the following themes were prominent: the need for fulfillment of emotional needs such as acceptance, acknowledgement, approval, love, warmth and caring, feelings of anger because of rejection, disappointment and frustration, grieve, uselessness and apprehension, but not gladness. The inability to make decisions and identify problems, the lack of motivation, the lack of internal locus of control, ambivalent feelings regarding the future and the quest for wholeness reflect the deliberation processes (Peens, 1995,118).

A lack of effective control mechanisms, probably due to the lack of role models and support systems, lead to the inability of adolescents with mental health problems to accept, adapt and integrate their situations as part of their lives. This is embodied in the development of eating disorders, alcohol abuse and dependency, violence and aggressive behaviour, conflict between parents and adolescents, withdrawal of the adolescent 
from others, the school and the community and eventually isolation, loneliness and destructive behaviour.

\section{This is reflected in the following quotations:}

\author{
"As daar "n snytjie brood weg is ... EK!" ("If a slice of bread is \\ missing .. ME!"
}

"Jy begin drank en dwelms gebruik om ... net te vergeet .. dit het my vir ' $n$ rukkie beter laat voel .. dan drink jy weer ... 'n aanhoudende proses .. en later kan jy nie meer daarsonder nie..." ("You start drinking and using drugs to .. just forget ... I felt better for a while .. then you drink again ... a continuous process .. and after a while you can't do without...”)

"Jy begin agter raak met jou skoolwerk.. jy sien net nie meer kans vir enige iets nie..." ("Your school work lags behind .. you don't see your way open for anything ...")

".. en hy het my en ma ma gewoonlik geslaan." (".. and he normally hit me and my mother.")

"... op die ou end ontplof die pot tog maar." (".. in the end the pot eventually explodes.”)

"... ek het moeg geword vir dat ek en my ma slegter is as kennisse met mekaar..." ("I got tired of merely being an acquaintance to my mom...")

"Jy wil net alleen wees." ("You just want to be left alone.”)

"Jy voel baie eensaam om 'n probleem te hê." ("You feel very lonely having a problem.”)

During times of acute stress adolescents with suicidal thoughts and behaviour find it extremely difficult to adopt new coping mechanisms or to explore alternatives. The adolescents indicated the same voids and characteristics reflected in family relationships, for example unstable relationships, emotional and physical conflict, rigidity and alcohol and/or drug abuse. Controlling the problems can result in depression, suicide and eating disorders (internalized) or violence to property and/or people. use of drugs or alcohol, sexual activity, disturbing relationships (externalized) (Puskar, Hoover \& Miewald, 1992:15-20; Brendt, Johnson \& Bartle, 1993:7; McKay, Murphy, Rivinus \& Maisto, 1991:967; Kurtz, Kurtz \& Jarvis, 1991:543; Falla \& Jones, 1991:41-50; Barber, 1992:71). The description of the life world of adolescents with mental health problems reflected that all four adolescents presented suicidal thought and behaviour, depression, anxiety, impulsive and self-destructive behaviour, a low self-image and lacking locus of control.

"Ek het angsaanvalle gekry van stres." ("I has anxiety attacks due to stress.")

"...en ek was bang." (“.. and I was scared.”)

"... toe probeer ek selfmoord pleeg." (“ ... I then tried to commit suicide.")

"Ek was moeg en siek en sal vir almal." ("I was tired and fed up with everybody.")

"'”kk was vrekbang vir hom." ("I was very scared of him.")
“.. en dit dryf jou dan na selfmoord." ("...and that drives you to suicide.")

"Ek is baie afgekraak. En ek word baie vinnig seergemaak..." ("I was denigrated often. And I am easily hurt....")

"Op die ou end makk dit jou so bang .." ("In the end it scares you very much...")

"Ek wil myself ophang.") ("I want to hang myself.")

Adolescents exposed to social and relationship losses, feelings of hopelessness and anxiety, a low self-esteem, bad interpersonal relationships and conflict and a concurrence of events, are confronted with suicide as a way to escape this world (De Wilde, Klenhorst, Diekstra \& Wolters, 1993: 51-57; Spirito, Hart, Overholzer \& Halverson, 1990:543-545).

Alternativeiy parental acceptance, interest, closeness, warmth, respect and positive feed-back enable the adolescent to obtain and confirmed ego-identity, a positive self-image, the ability for complex argument, to be less impulsive and to engage in more intimate interpersonal relationships (Bar-Joseph \& Tzuriel, 1990:213; Isberg, Hauser, Jacobson, Powers, Noam, WeissPerry \& Follansbee, 1989:2; Younge, Rathge, Mullis \& Mullies, 1990:334)

When experiencing depression, adolescents' lives are indicative of an inability to self-differentiation which can unlock the world of self-development for the adolescent and facilitate emotional maturity. Badly differentiated adolescents are easily influenced by emotional events and literally move form one crisis to another, as indicated in the life world of adolescents with mental health problems. It weakens academic achievement, social ability, career choices and self-assurance. The functioning at school, socialization, self-assurance and future expectations weaken the adolescent with mental health problems (Fagan-Pryor \& Harber, 1992:24-27; Ehrenberg et al, 1991: 361-363; Lewisohn, Rohde \& Seeley, 1993:60; Young et al, 1990:333). All three girls who participated in writing the life world of adolescents with mental health problems had at one time or another, been sexually molested and/or raped:

"Toe ek in graad een was het hy my seksueel begin molesteer." ("I was in grade one when he started molesting me sexually...")

“..en toe op "n dag verkrag hy my...” (“.. and then one day, he raped me....")

"Vir B was vat en voel nie genoeg nie. Toe het hy my verkrag." ("For B touching and feeling were not enough. He then raped me.")

"...my ma se beste vriendin se seun en die se maat het my verkrag." (“... my mom's best friend's son and his friend raped me.")

This leads to emotional pain, loss of human dignity, depression, unhappiness, feelings of worthlessness, guilt, worry and concern regarding relationships, especially towards the opposite sex, with a subsequent lack of self-assurance, a low selfimage and loss of scholastic capabilities and eventually sui- 
cidal threats and attempts. This is confirmed in the literature (Robertson \& Simons, 1989:125; Simons \& Miller, 1987:326328; King, Naylor, Segal, Evans \& Shain, 1993;745).

The social dimension refers to the "organizational structures among people and communities, in other words all human resources." (Poggenpoel, et al, 1994:132).

The social dimension of the life world of the adolescent with mental health problems reflects the need for stability and a place to belong, lack of effective functioning at school, at home and in the community and a lack of significant others and support systems, with the parent as the most important support source (Peens, 1995:118).

Meaningful and significant resources for the adolescent involve a place to live, parents who care and who don't continuously try to restructure families, the availability of someone, especially the parent who can listen, mutual trust and dependable support systems. Unfortunately the life story of the adolescent with mental health problems are indicative of a lonely, desolate world where heartache, pain and rejection are the main themes:

"..en ons het by my ouma-hulle aan bly..." (“.. and we went to live with my grandparents.")

"Toe trek ons weer na " $\mathrm{n}$ ander woonstel." ("We then moved to another flat.")

"In Desember het ek uitgevind my pa gaan weer trou, dit het my gebreek..." ("I discovered in December that my dad was remarrying, that broke me...")

"Hulle moes trou..." ("They had to get married....")

"Alles het begin verkeerd loop toe ek tien geword het .. dit was toe my ma en oom E getrou het..." ("Everything started going wrong when I turned ten.. that was when my mother and uncle E got married...”)

"... en toe trou my ma weer..." ("and then my mother remarried.")

"Ek dink my ouers behoort daar te wees." ("I thin my parents should be there.")

"Sy het byna nooit iets saam met my gedoen nie." ("We almost never did anything together.")

"My ma was nooit daar nie." ("My mother was always absent.")

"Ag wat, jy kan hulle tog nie vertrou nie..." ("What's the use, you can't trust them...”)

"Maar jy het niemand om dit voor te vertel nie.." ("But you have no one to share it with..")

“...want niemand help jou nie.” (“..because nobody helps you...")

“..en hulle is ook nie daar nie." (“..and they are also not there.”)
"My hond hou my aan die lewe." ("Mydog keeps me alive..")

Minuchin (1974:47) is of the opinion that "human experience of identity has two elements: a sense of belonging and a sense of being separate."

The need to change the established balance between "to belong" and "to part" in order for the adolescent to become more and more autonomous, becomes prominent especially during adolescence (Roelofse \& Middleton, 1985:34)

The description of the life world of the adolescent with mental health problems indicates, however, that the adolescent with mental health problems have little experience of healthy and supportive family relationships and is caught up in the need "to belong" and is continuously looking for a place to stay; a place of his own. Special friendships are one of the ways adolescents get an opportunity to develop networks for personality development. socialization, bettered self-esteem and identify development, enlargement of logical analysis, ideologies, social institutions and equality in relationships (Brendt. 1982:1447-1460). The life stories of adolescents show little indication thereof, but the reference to loneliness, isolation and withdrawal, creates the impression that the adolescent with mental health problems has a lacking or superficial circle of friends and support system.

The nature of relationships in marriage and the family, the communication patterns, the atmosphere in the family, respect for and acceptance of humanity and modeling of conflict management and decision-making, determine the adolescent's socialization skills. The experience and interpretation of relationships outside of the family, friends and peer group and a variety of other information sources, determine another facet of socialization. The development of a rich social perception and value system, contributing to the identity development of the adolescent, depend on the above (Bulcroft, 1991:89; Niemi, 1988:431-432, 441-442; Shulman \& Prechter, 1989:440-441; Papini \& Sebby, 1987: 2,3, 11-12.

The life stories of adolescents with mental health problems, however, reflect a lacking exposure to modeling relationships on the one hand, and a lacking exposure to friends, on the other hand, resulting in a restricted social perception and value system and eventually a lacking identity development:

"My ma het probeer om haar probleme weg te drink." ("My mother drank, trying to get rid of her problems.")

"Ek is verwurg en geklap dat ek bo-oor "n dubbelbed trek." ("I was strangled and hit. and went flying over a double bed.")

"Ek wou net wegkruip van alles en almal." ("I wanted to hide from everything and everybody.")

"Jy lê daaronder waar niemand vir jou omgee nie." ("You lie down, right at the bottom, where nobody cares.")

“...as mense my nie wil aanvaar soos ek is nie." ("..if people don't want to accept me the way I am.”)

“...dat ek maar baie eensaam is..." ("...that I am, in fact. very 
lonely....")

Subsequently, the spiritual dimension of the life world of the adolescent with mental health problems is investigated and described, and verified according to the literature. A spiritual dimension refers to the "significant spiritual element or occurrence in the (adolescent's) environment which includes values, beliefs, norms and ethical principles, religion and meaning in life as well as relationships with others and God." (Poggenpoel, et al, 1994:132).

The following themes were identified in the life world of the adolescent with mental health problems: mental poverty and a need of a relationship with God; loss of and a need for the sense of life: existential crisis, loss of self-worth, including a loss of dignity, control (identity crisis), changing role definitions, and the quest for wholeness; disturbance in interpersonal relationships and need of assistance, role models, support systems, listening, trust and understanding, and therapeutic intervention (Peens, 1995:118).

One of the developmental assignments of the adolescent is to develop a personal value system. Cognitive abilities and abstract thoughts, as well as parental attitude, a warm family climate, the peer group, religion practice and guidance are prerequisites for the questioning, judgement and establishment of an own value system and influences the nature of the adolescent's norms and moral development (Low, Gerdes \& Meyer, 1985:367-372; Bell \& Bell, 1982:519; Zern, 1991:271).

The adolescent with mental health problems' life story reflects emotional poverty overflowing in negative thinking patterns and thoughts that complicate cognitive, rational and abstract thinking and subsequently influence the establishment of a value system. The need for religion and a relationship with God in obtaining help, strength and courage, without reference to an intimate religious relationship, confirms the search for a value system, after the establishment of norms and moral development (Peens, 1995: 129).

The adolescents describe it as follows:

“..want ek kan net na die Bybel toe gaan en dit oopslaan ... moenie moedeloos wees nie ... dit gee vir my nuwe krag, en dan gaan ek aan." (“...because I only need to open the Bible.... don't despair...that gives me courage, and I can continue.")

“... ons kan saam bid vir die Here..." (“... we can pray together...")

"Hy beantwoord ons gebed, maar op Sy manier, soos Hy dink dit is reg." ("He answers our prayers, according to His will.")

"Jy moet op God vertrou." ("You must have trust in God.")

"...en bid en hoop..." (“..and pray and hope...”)

"Godsdiens speel 'n baie belangrike rol in my lewe." ("Religion plays a very important role in my life.")

"Ek dink die grootste is bid, vertrou op God. God sal help..." (I think the greatest is prayer, trust in God. God will help..")

"Ek dink iets wat dalk help is geloof ..jy ... as jou geloof in God sterk is..." ("I think something that helps is religion ... you ... if you have a strong belief in God..")

\section{"As jy vir die Here vir krag gevra het..." ("If you have asked the Lord for courage...")}

The adolescent, however, acknowledges frustration with God and religion:

“...en ek dink almal van ons moet nog eendag die Here sê hoekom ons alles gedoen het..." (“....and I think all of us will someday have to tell God why we did everything...")

"Partykeer kan dit ook 'n struikelblok wees want jy ... jys is jy, jy is kwaad vir God oor wat gebeur het - jy gaan nie na Hom toe vir hulp nie - en dan kan Hy jou nie help nie." ("Sometimes it can be an obstacle, because you, ... you are you, and you are angry with God because of what happened - and you don't approach Him for help - and the He can't help you.")

"Hy beantwoord ons gebed, maar op Sy manier .. hmmm .. soos wat Hy dink dit is reg. Partykeer dink ek maar ek wil dit nie later hê nie, ek wil dit nou hê, want ek het dit nou nodig, so..." ("He answers our prayers, but according to His will, I sometimes think I don't want it later, I want it now, because I need it now, so...")

The process in obtaining independence requires the adolescent to accept more responsibility and make his own decisions. Although the peer group plays an important role, the family's influence is indispensable. "the family is an important laboratory in decision-making" (Brown \& Mann, 1990:25-28.

Communication and support, empathetic understanding and mutual trust in the family facilitate emotional linkages and adaption regarding power structures and role expectancies (Masselam, Marcus \& Stunkard, 1990:726, 735-736; Noller \& Callan, 1986:97, 105; Noller, Seth, Smith, Bouma \& Schweitzer, 1992:113; Robertson \& Simon, 1989:126-128). The opposite, however, is true of the adolescent with mental health problems where communication abilities, support, empathy and trust are lacking. Feelings of anxiety, distrust, hopelessness, self-hate, isolation and rejection and the loss of sense and meaning, eventually result in suicidal thoughts and behaviour:

"Jy moet eers daardie vertroue kry." ("First of all you have to gain that trust.")

"Ek vertrou nie mense maklik nie." ("I don't easily trust people.")

"..want as jy teleurgesteld is kan jy nie weer vertrou nie." ("..because if you were disappointed, you can not trust again.")

"Ek vertrou nie maklik mense nie omdat ek al te veel teleurgestel is." ("I don't trust people easily, because I have been disappointed once too often.")

"Herinneringe maak jou moeg ... dit maak jou seer en negatief .. alles weer van voor af." (Memories tire you ... it hurts you and make you negative .. everything all over again.")

“..ek het 'n muur om my gebou vir jare al..." ("for many years, I have built a wall around me...") 
"Ek voel, ek voel... verward, uitgeslote, uit hulle harte uitgestoor." ("I feel, I feel . confused, excluded, pushed from their hearts.")

“.. verwerp, sy gee nie meer om nie.” (“..rejected, she does not care any more.")

“..want jy bou op en bou op en hou uit en hou uit .. en dan. dan al hoe jy kan leer om dit te verwerk is om angsaanvall te kry ... dit uit te bring." ("..because it builds up and builds up, and persevere and persevere .. and then, the only way to adapt it to have an anxiety attack .. to discard it.")

"Die dinge raak te erg, so bedreig en bedruk." ("Things are getting too much, so endangered and oppressed.")

"..en dit dryf jou dan na selfmoord..." ("..and that makes you commit suicide...")

"Ek het probeer selfmoord pleeg deur 'n oordosis slaappille te drink en my polse te sny ... ek het my polse herhaaldelik gesny.." ("I tried to commit suicide by taking an overdose of sleeping tablets and cutting my wrists. I repeatedly cut my wrists...")

The preceding indicates a dynamic interaction between the psychological, social and spiritual dimensions. The intense entanglement and circularity of the interactions enrich, but at the same time obstruct the description of the total life world of the adolescent with mental health problems. The researcher suffices with the following characteristics of interaction: The longer the time frame of the problems, the more intense the experience of the problem and the greater the adolescent's inability to control his emotions, thoughts and behaviour and develop effective coping mechanisms. The inability to judge and differentiate becomes more and more defused and it becomes almost impossible to create change. It appears over and over again that the social dimension, which is nearly saturated with a lack of and absence of support and significant others, paralyses that little "strength" that might be left in the psychological dimension.

Ineffective coping mechanisms result in more pain and hurt. anger and frustration, despondency and hopelessness and powerlessness and eventually present an increased loss of control of thought, emotion and behaviour. A decrease in selfworth because of the above and a loss of dignity becomes more and more prominent as the period of ineffective coping with problems increases.

Experience of rejection is so intense that the losses normally experienced with rape are minimal; rather raped than rejected! The need of acceptance, acknowledgement. approval and security becomes more intense and more ignored. The adolescent becomes more powerless to take control of his realization that there is nobody who can help, becomes a bigger reality as the vicious circle grows. The experience of uselessness and senselessness leads to existential and identity crises and eventually culminates in destructive behaviour and suicide attempts. It is only after intervention after a suicide attempt that the adolescent with mental health problems realizes the need for external help; from God, a therapist, anybody who can help! Therefore the perceptions "nobody cares" and "nobody wants to help" are bigger than the need to be helped. Eventually the interference realizes something of the need for the quest for wholeness (Peens, 1995:131-132).

The researcher suffices with the description of the life world of the adolescent with mental health problems. Following are the conclusion and recommendations

\section{Conclusion}

The description of the life world of the adolescent with mental health problems increases the researcher's awareness of the intense emotional experience of the adolescent and conceals the hope and quest for wholeness. Although a couple of themes were identified for the description of the life world of the adolescent with mental health problems, and was confirmed in the literature, the researcher came across a couple of new insights not reflected in the literature survey.

- The various needs of the adolescent, whether he is mentally healthy or mentally ill, were not described in the literature.

The following needs were highlighted in the description of the life world of the adolescent with mental health problems:

- $\quad$ need for the fulfillment of emotional needs;

- $\quad$ need for the quest for wholeness;

- $\quad$ need for stability and a place to belong;

- $\quad$ need for sense and meaning;

- $\quad$ need for a relationship with God;

- $\quad$ need for support systems;

- need for listening, understanding and trust.

The literature does, however, refer to various emotions, the importance of a place to belong and support, but not from a perspective of "need". The importance of listening, trust and understanding is discussed, but as a possibility to strengthen family relationships and not as therapeutic intervention. The need for a relationship with God and the quest for wholeness are totally unique (Peens, 1995:133).

- $\quad$ The lack and inability to identify and use support systems and sources early enough. All four adolescents who participated in writing the life world of the adolescent with mental health problems have nearly been helped too late.

- $\quad$ Some aspects of the life stories of the adolescents with mental health problems could not be found in the literature.

- Nowhere in the literature could the researcher find anything of an experienced or life world description of the adolescent with mental health problems and the totality approach combined with the experienced world and therefore a unique contribution to the research.

- The information gathered from the literature is coupled to specific behavioural and/or emotional problems and specific diagnoses between signs and symptoms. A diagnostic medical model, prescriptive by nature, was used. The expert is therefore the one who does the 
prescribing. The researcher found nothing in the literature that was initiated by the adolescent; only technical scientific explanations and data processed in theories and models.

- The adolescent with mental health problems is, however, according to the description of the life world of the adolescent with mental health problems, the expert and he is not singularly busy constructing his own life world on the basis of his structural determination, but also writing and rewriting his own life story.

- $\quad$ The themes of pain and hurt, losses and unfulfilled emotional needs and lacking support systems in the life world of the adolescent with mental health problems overflow the adolescent to such an extend that there is no room left for an increased quest for independence and acceptance of responsibility and the completion of the developmental tasks of the adolescent (Peens, 1995:133-136).

The researcher only mentions new insights in the conclusion. To total description of the life world of the adolescent with mental health problems was taken onto consideration when recommendations for nursing practice, education and research were made.

\section{Recommendations}

The researcher suggests that should the following recommendations be implemented in nursing practice and the adolescent with mental health problems is supported as expert with guidance, support and care, there is room for writing and rewriting the life story of the adolescent, a life story with new meaning, hope and a quest for wholeness and the improvement of mental health can be maintained and repaired. There should therefore be room for:

- acquiring coping mechanisms and life skills; a role model and an uplifting atmosphere for the modelling of socialization, relationships, value systems and religious convictions;

- $\quad$ a source of support by the psychiatric nursing specialists, parents and friends; a sensitive ear to listen to the emotional pain, needs and internal conflict;

- $\quad$ acceptance and acknowledgement, the obtaining of a positive self-image, dignity and self-assurance, discovery of the self, an own identity and self-differentiation.

- $\quad$ Recovering of control and management of losses, reuniting ("re-membering") family ties and the facilitation of a positive family atmosphere; obtaining a future and job orientation and vision;

- $\quad$ A place to belong; mental support with subsequent discovery of sense and meaning;

And the quest for wholeness and realization of hope.

The availability of someone worthy of relationships and who can listen, comprehend and understand (participating assessor), who wants to get involved and has sufficient time for the adolescent with mental health problems to create and construct and co-construct and let him tell his life story, can make a difference.

The change manifested by interaction and dialogue as healing factors that realizes wholeness and hope, can provide the adolescent with room to rewrite his story and allow him to add new meanings (Peens, 1995:137-140).

The voids in various psychiatric nursing science curricula of nursing education regarding adolescent psychiatric nursing and family and marriage therapy should be addressed. In the description of the life world of the adolescent with mental health problems, it clearly shows the intense need for family involvement, that can be facilitated by family therapy and parental guidance and/or psycho-didactic groups, and broken marriages can be addressed by marriage therapy and/or counseling. These aspects are normally presented on a post-graduate level, but becausc of the shortage of sufficient psychiatric nursing specialists in the adolescent psychiatric practice, it is recommended that this void is addressed in special curricula (Peens, 1995:207).

The researcher concludes that a different approach, apart from the medical model, should be generated and addressed in nursing research where an extensive, totality approach, in which the life world of the adolescent with mental health problems with all its meanings and experiences are respected and maintained and fragmentation, diagnosis, labeling and evaluation maintain a low profile (Peens, 1995:138). 


\section{Bibliography}

ABDELLAH, FG \& LEVINE, E 1979: Better patient care through nursing research. Second edition. New York: MacMillan.

BARBER, BK 1992: Family personality and adolescent problem behaviours. Journal of Marriage and Family. 54, Feb. 1992:69-79.

BAR-JOSEPH, H \& TZURIEL, D 1990: Suicidal tendencies and ego identity in adolescents. Adolescence. XXV (97), Spring 1990: 215-223.

BELL, LG \& BELL, DC 1982: Family climate and the role of the female adolescent: Determinants of adolescent functioning. Family Relations. 31. 1982:519-527.

BRENDT, DA; JOHNSON, B \& BARTLE, S: et al. 1993: Personality disorder, tendency to impulsive violence and suicidal behaviour in adolescents. Journal of the American Academy of Child and Adolescent Psvchiatrv. 31(1). Jan. 1993:69-73.

BRENDT, TJ 1982: The features and effects of friendship in early adolescence. Child Development. 53, 1982:1447-1460.

BROWN, J \& E MANN, L 1990: The relationship between family structure and process variables and adolescent decision making. Journal of Adolescence. 13, 1990: 25-37.

BULCROFT, RA 1991: The value of physical change in adolescence: consequences for the parent-adolescent exchange relationship. Journal of Youth and Adolescence. 20(1). 1991:89. 105.

DE WILDE, EJ; KIENHORST, ICWM; DIEKSTRA, RFW \& WOLTERS, WHG 1993: The specificity of psychological characteristics of adolescent suicide attempters. Journal of the American Academv of child and Adolescent Psychiatry. 32(1), Jan 1993:51-58.

EHRENBERG, MF; COX,DN \& KOOPMAN, RF 1991: The relationship between self-efficacy and depression in adolescents. Adolescence, 26(102), Summer 1991:361-373.

FAGAN-PRYOR, EC \& HABER, LC 1992: Co-dependency: another name for Bowens' undifferentiated self. Perspectives in Psvchiatric Care. 28(4), Oct-Dec 1992: 24-27.

FAILA, S \& JONES, LC 1001: families of children with developmental disabilities: An examination of family hardness. Research in Nursing Health. 14. 1991:41-50.

GIORGI, A 1985: Phenomenology and psychological research. Pittsburgh: Duquesne University Press.

GUBA, EG 1981: Criteria for assessing the trustworthiness of naturalistic inquiries. Educational resources information centre annual review paper. 29, 1981:75-91.

ISBERG, RS; HAUSER,ST; JACOBSON, AM; POWERS, SI; NOAM, G; WEISS-PERRY, B \& FOLLANSBEE, D 1989:
Parental contexts of adolescent self-esteem: a development perspective. Journal of Youth and Adolescence. 18(1), 1989: 1-21.

KERLINGER, F 1986: Foundation of behavioural research. New York: Holt, Rinehart \& Winston.

KING,CA: NAYLOR,MW; SEGAL,HG; EVANS, T \& SHAIN, BN 1993: Global self-worth, specific self-perceptions and competence and depression in adolescents. Journal of the American Academy of Child and Adolescent Psychiatry. 32(4). July 1993: 745-751

KINGRY, MJ; TIEDJE, LB \& FRIEDMAN, LL 1990: Focus groups: A research technique for nursing. Nursing Research. 39(2), March/April 1990:124-125.

KOTZE. DJ 1992: Verantwoordelikheid as antropologiese essensie. Pretoria: Universiteit van Pretoria. (Doctor Divinitatis -Proefskrif).

KREFTING, $L$ 1991: Rigor in qualitative research: The assessment of trustworthiness. The American Journal of Occupational Therapy. 45(3). 1991:214-222.

KURTZ, PD; KURTZ, GL \& JARVIS, SV 1991: Problems of maltreated runaway youth. Adolescence. 26(103). Fall 1991:543555 .

KVALE, S 1983: Journal of phenomenological psvchology. 14, 1983:171-196.

LEWINSHOHN, PM; ROHDE, P \& SEELEY, JR 1993: Psychosocial characteristics of adolescents with a history of suicide attempts. Journal of the American Academy of Child and Adolescent Psvchiatry. 32(1). January 1993:60-67.

LINCOLN, YS \& GUBA, EG 1985: Naturalistic inquiry. Beverly Hills: Sage Publications.

LOUW, DA; GERDES, LC \& MEYER, WF 1985: Menslike ontwikkeling. Pretoria: HAUM.

MARSHALL, C \& ROSSMAN, GB 1989: Designing qualitative research. Newbury park: Sage Publishers.

MASSELAM, VS; MARCUS, RF \& STUNKARD, CL 1990: Parent-adolescent communication, family functioning and school performance. Adolescence. XXV(99), Fall, 1990:725737.

McKAY,JR; MURRAY, RT; RIVINUS, TR \& MAISTO,SA 1991: Family disfunction and alcohol and drug use in adolescent psychiatric inpatients. Journal of the American Academy of Child and Adolescence Psychiatry. 30(6), Nov. 1991:967972.

MERRIAM. SB 1991: Case study research in education. A qualitative approach. San Francisco: Jossey-Bass Publishers.

MINUCHIN, S 1974: Families and family therapy. Cambridge: Harvard University Press.

MOUTON, J \& MARAIS, HC 1988: Metodologie van die 
geesteswetenskappe: Basiese begrippe. Pretoria: RGN.

NIEMI, PM 1988: Family interaction patterns and the development of social conceptions in the adolescent. Journal of Youth and Adolescence. 17(5), 1988: 429-443.

NOLLER, P; SETH-SMITH, M; BOUMA, R \& SCHWEITHZER, R 1992: Parent and adolescent perceptions of family functioning: A comparison of clinic and non-clinic families. Journal of Adolescence. 15, 1992: 101-114.

NOLLER, P \& CALLAN, VJ 1986: Adolescent and parent perceptions of family cohesion and adaptability. Journal of Adolescence. 9. 1986:97-106.

OMERY, A 1983: Phenomenology: A method for nursing research. Advances in Nursing Science. 5(2), Jan 1983:49-63.

ORAL ROBERTS UNIVERSITY: ANNA VAUGHNSCHOOL OF NURSING 1990: 136-142: Self-study report, submitted to the Council of Baccalaureate and Higher Degree program, National League of Nursing, August 1990. Volume 1-Narrative by Criteria. Tulsa, Oklahoma: Oral Roberts University: Anna Vaughn School of Nursing.

PAPINI, DR \& SEBBY, RA 1987: Adolescent pubertal status and affective family relationships: A multivariate assessment. Journal of Youth and Adolescence. 16(1) 1987:1-13.

PEENS, T 1995: ' $n$ Psigiatriese verpleegkundige benadering van adolessente met geestesgesondheidsprobleme. Johannesburg: Randse Afrikaanse Universiteit. (D. Cur. Proefskrif).

POGGENPOEL, M; NOLTE, A; DöRFLING, C; GREEFF, M; GROSS, E; MULLER, M; NEL, E \& ROOS, S 1994: Community views on informal housing environment: Implications for health promotion. South African Journal for Sociology 25(4). 1994:131-136.

POLIT, D \& HUNGLER, BP 1989: Essentials of nursing research. Second edition. Philadelphia: J B Lippincott Company.

PUSHKAR, K; HOOVER, C \& MIEWALD, C 1992: suicidal and non-suicidal coping methods of adolescents. Perspectives in Psvchiatric Care. 28(2), April - June 1992:15-20.

ROBERTSON, JF \& SIMONS, RL 1989: Family factors selfesteem and adolescent depression. Journal of Marriage and the Familv. 5, Feb. 1989: 125-138.

ROELOFSE, R \& MIDDLETON, MR 1985: The family functioning in adolescence questionnaire: A measure of psychosocial family health during adolescence. Journal of Adolescence, $8,1985: 33-45$.

WHULMAN, S \& PRECHTER, E 1989: Adolescent perception of family climate and adaptation to residential schooling. Journal of Youth and Adolescence. 18(5), 1989: 439-449.

SIMONS, RL \& MILLER, GM 1987: Adolescent depression: Assessing the impact of negative cognition and social-environmental problems. Journal of the National Association of
Social Workers. 32(4), July-Aug 1987: 326-330.

SPIRITO, A; HAR I, K: OVERHOLZER,J \& HALVERSON, J 1990: Social skills and depression in adolescent suicide attempters. Adolescence, XXV(99), Fall 1990:543-551.

VAN REENEN, MG 1993: 'n Keuringsmodel vir voornemende kandidate in gevorderde psigiatriese verpleegkunde. Johannesburg: Randse Afrikaanse Universiteit (D. Cur. Proefskrif).

WALSH, BJ \& MIDDELTON, JR 1984: The transforming vision: shaping a Chirstian world view. Downer's Grove, Illinois: Intervarsity Press.

WOODS, NF \& CATANZARO, M 1988: Nursing research: theory and practice. St. Louis: Mosby.

YIN, RK 1989: Case study research, design and methods. Applied sucial research methods series: Volume 5, Second edition. London: Sage Publications.

YOUNGS, GA; RATHGE, R; MULLIS, R \& MULLIS, A 1990: Adolescent stress and self-esteem. Adolescence. XXV(98), Summer 1990:333-341.

ZERN, DS 1991: Stability and change in adolescent's positive attitudes towards guidance in moral development. Adolescence. 26(102), Summer 1991: 261-272. 